\title{
A Historical Sketch of the Landscape of the Red River Delta
}

\section{Li Tana}

\begin{abstract}
This article is an attempt to stand back and re-imagine the landscape of the Red River over the last two millennia. The only static components of the Red River valley and delta are its mountains and geological deposits, everything else has changed over time. By marrying historical records with recent scientific findings on the Red River, this article outlines aspects of these changes; including changes to the climate and landscape, the possibility of shifting river courses, the movement of historical trade routes, and the rise of Thang Long-Hanoi.
\end{abstract}

KEYWORDS: History, Red River, Yunnan, Vietnam, Hanoi

\section{INTRODUCTION}

W HILE WATER IS A constant theme in the study of Vietnam, it is even more prevalent to our understanding of the Red River delta. With the treacherous Gulf of Tongking (also spelled Tonkin) at front and the unpredictable Red River at the back, water is constantly present in all scholarship - history, culture, agriculture, and folklores of the Red River delta. Yet at the same time, it is a subject with an ambiguous role. For centuries it has been exploited, and, as such, central to economic and social changes, but it is rarely the primary focus of scholarly research. In an effort to lay the ground for future scholarship, this short contribution offers a historical sketch of the Red River and seeks to answer some simple, but fundamental, questions: When did it start to be called the 'Red River'? Has the Red River always run the same track through the mountains? Has it created the same delta through the same course?

Over the last decade, significant advances have been made in scientific studies of the Red River. Research has been undertaken in sedimentation, pollen studies on climate changes during the Holocene, and sea level changes (Ayako et al. 2007; Li Zhen et al. 2005). Surveys of vegetation types and distribution in the Red River area were first carried out by a joint team of Chinese, Japanese, and Vietnamese scholars in 2007 (Li Jie et al. 2009), followed by a second joint survey on the Red River fault zone by Chinese and Vietnamese scholars (Zhang Jianguo et al. 2008). Scientists have been consciously crossing national 
boundaries and have treated the Red River catchment as one integral unit. Comparable efforts have yet to be made by historians.

In this article I attempt to marry historical records with the recent scientific findings on the Red River, while keeping an eye on the parallel histories of other major deltas in China and Southeast Asia. Following the Red River's $1100 \mathrm{~km}$ course through Yunnan and northern Vietnam, particular attention will be given to the changes of its main course, its role in shaping geographical morphology of successive eras, and the ways in which the river provided a context for human events. The article commences in contemporary Yunnan, where the Red River originates, and then focuses on the Red River delta of the last two millennia.

\section{Basic Figures on Upper and Lower Streams of the Red RIVER: LAST 200 YEARS}

The Red River is an unstable fluvial system whose geographical configuration has altered over the last thousand years. These changes are reflected in its colour, hence its name. Although the river has had a dozen names in history, the 'Red River' was never one of them, whether in Vietnamese, Chinese, Dutch, or Portuguese sources. The name 'Red River' first appears in French sources in the mid-nineteenth century. Prior to this Red River was known to the Vietnamese as the 'Big River' - 'Song Cai' (or the Major River). During the seventh century, this colloquial name was recorded by the Portuguese and Dutch on their maps of the delta. Its more formal name, the 'Thao', was originally used by Tai-Kadai speakers from the region. In Tai-Kadai, Nam Tao means Big River or Major River. The two oldest names for the Red River, 'Phu Luong' and 'Song Lo', appear repeatedly in Chinese records. According to a Vietnamese linguist Tran Tri Doi (2008: 1), both terms were of Austroasiatic language origin and mean 'River'. Thus, for the major course of the Red River's history, colour was never mentioned or recorded in any language other than French.

It might not be a coincidence that the adjective 'Red' appeared in the river's name in the mid-nineteenth century. Ecological degradation increased markedly both in southern Yunnan and northern Vietnam during the late eighteenth century. South-eastern Yunnan (Dongchuan, Chuxiong, Wenshan, and Hong $\mathrm{He}$ ) figures at the top of the list for direct loss of soil through erosion in Yunnan province. Today, forest cover in this region is a mere 19 per cent, second only to the smallest forested area, that of the provincial capital, Kunming (Yang Zisheng and Xie Yingqi, 1994: 102-104). The ecological situation of this area, adjacent to Vietnam, is considerably worse than that of the southwestern region adjacent to Burma. Chinese geologists in Yunnan identify the upper Yuan Jiang (Red River) as a dry-hot valley area and point out that the forest has been completely stripped away in areas below 1200 metres above 
sea level, leaving only “barren mountains and unruly waters” (“窮山惡水” Du 2005: 71).

Downstream at the Red River delta, a set of figures calculated by Vietnamese scholars (Le Bac Thao 1977: 142-143) is equally striking. In the 150 years between 1831 and 1959, the delta land progressed by 19 kilometres, at a speed of 161 metres per year. This contrasts sharply to the earlier period between 1471 and 1830, when the speed was merely one-eighth of the later period, at 21 metres per year. This speed over the last 150 years is salient when compared with the two major deltas in southern China, the Yangzi and Pearl rivers, whose land progression over the last 250-300 years was 48 metres and 32 metres respectively. As such, the Red River is comparable to the Yellow River, notorious for its quick siltation (136 m/y between 1811 and 1855, and $191 \mathrm{~m} / \mathrm{y}$ between 1856 and 1972) (Elvin and Su 1998: 351, 363; Huang and Li 1982: 4; Pan and Si 1979: 399-401).

Significantly, the rate of land progression of the Red River delta accelerated only in the last two centuries, and it was then that the Red River made itself comparable to the Yellow River. What happened in the upper stream of the Red River? Two major activities began taking place in Yunnan in the last 300 years that can be highlighted. First, the mining of gold, silver, copper, tin, zinc, and iron began on a large scale from the late seventeenth century. Three hundred thousand labourers were reportedly working in these mines between 1700 and 1850 (Lee 2012: 115). By the late nineteenth century, Gejiu, the border town near the Yunnan-Vietnam border became known as the 'Tin capital' of China. Second, in the eighteenth century, New World crops, especially corn and potatoes, were first planted on the slopes of the headwater valleys of the Red River catchment. Their high yields and low labour input attracted migrates from Hunan, Hubei, Sichuan, and Guizhou, who settled particularly in the YunnanVietnam border areas. By the early nineteenth century, the migrant population exceeded the indigenous population resulting in a large area of deforestation.

The most damaging consequence of these technological and agricultural transformations was the erosion of the soil cover from the limestone hills which once removed is very difficult to remedy. ${ }^{1}$ Yunnan scholars record that forest cover in Yunnan diminished and sedimentation increased dramatically from 1959 onward (Ren et al. 2006: 146). Dike breaches in the lower Red River area increased at an alarming rate in the nineteenth century. While there were only three recorded breaches in the eighteenth century, in the nineteenth century dikes broke in 48 different years; a rate of almost once every other year. The largest recorded flood in the Red River delta occurred in August 1971.

\footnotetext{
${ }^{1}$ Surveys on soils of southern China show that cover of red, yellow, purple soils in limestone area is between 0.5 and 1.2 meters. The rate of erosion of such areas is between 2 and $10 \mathrm{~mm}$ per year. With no measure of land protection, the top soil might disappear sometime in the next 50 and 450 years (周琼: ‘18 19 世纪云南玉米和马铃薯的生态史研究”. Available at: http://economy.guoxue. com/?p=1102, accessed on 16 May 2014).
} 
Twenty-eight million tons of sediment was transported over ten days; the equivalent of the sediment load of seven consecutive dry seasons (Hoekstra and van Weering, 2007: 506).

There is no doubt that what happened in the upper catchment area of the Red River in Yunnan has had a serious impact on the lower reaches of the Red River delta. However, it is crucial to understand that the large scale development of the upper Red River on the Yunnan plateau commenced about ten centuries later than that of the Red River delta downstream. To understand the two thousand year history of this riverine region, one must look to the lower stream and the delta as we will in the next section.

\section{Crucial Aspects about the History of the Red River Delta}

The current waterways of the Red River delta appear to have only become fixed during the last few centuries. This is demonstrated by the names of the sea gates. There are currently eight sea gates, and none of their names existed before the seventeenth century. The Red River is not unique in this way, many rivers experience fundamental changes of course. The river systems in the Yangzi delta, for example, became increasingly fixed during the Song period (960-1279 AD). Shiba Yoshinobu points out that the fundamental engineering works of water control in this delta were carried out between the eighth and thirteenth centuries (Shiba 2000: 135). The river system of the Pearl River delta was fixed more recently, between the fourteenth and eighteenth centuries. The Ming era saw all six of the old paleo-tributaries of the North River silted while one river was formed (Chen 2008: 75-76). The Pearl River delta did not even appear before the early twentieth century. Major changes to the courses of the three major rivers in China seemed to have taken place between the eighth and the nineteenth centuries, increasing over the last 800 years.

In Cambodia, recent research by Buckley et al. at Angkor (2014), shows that most of Angkor's major public works including temples and water infrastructure such as the baray (or reservoirs) were built during the twelfth and thirteenth centuries, with the last baray having been built in late twelfth century. This would have altered the river systems considerably. In Indonesia, Stephen Druce reconstructed the former course of the major river, the Saddang River in South Sulawesi, between AD 1200 and 1600, and points out that its shifting direction caused a series of socio-economic changes in the island (Druce 2009; see also Macknight 1983). These studies conducted in other Southeast Asian regions suggest that similarly interesting revelations may come to light from a history of the Red River delta.

In their study on the Holocene sedimentary architecture of the Red River delta, Steve Mathers and Jan Zalasiewicz (1999: 324) highlight the possibility 
of abandoned tidal flat/creek systems in the delta, but state that this is speculative, and that the degree to which these channels migrated laterally to rework the tidal flats is not known. The map of the Red River at the Hanoi section (Figure 1) indicates the paleo-channel course of the Red River and many changes around this area. This map indicates that the river was about 2-3 times wider and more winding, and that there were many differences between the past and present courses of the Red River, evidenced by numerous oxbow lakes. More importantly, a considerable section of the old course of the Red River was on the eastern delta. The map further indicates that the Ngu Huyen Khe [Creek of the Five Districts], now an insignificant creek of the Duong river, used to be a part of the main arm of the Red River. This would present a rather different picture of the Red River, which, presently is dominated by the western delta centred at Nam Dinh. At one time, however, the Red River was very different and mainly ran through the eastern delta, centred on the Bac Ninh area.

In the tenth century, Ngu Huyen Khe was still a river called Ngu Huyen Giang ('River of the Five Districts'). Since it used to run through the five districts of Yen Lang, Kim Anh, Dong Ngan, Yen Phong and Tien Du, it was a long and important river (Dao 1964). It was this river which ran between the two oldest capitals of the Red River delta: Co Loa, the Viet king An Duong Vuong's capital; and Luy Lau (Long Bien), Jiaozhi's capital under the Eastern Han. Thus, between the first and eighth centuries AD, this riverine area was the heart of the civilisation of the Red River delta. Its central location was also recognised by the regions's Tai speakers. Many place names in this area have a

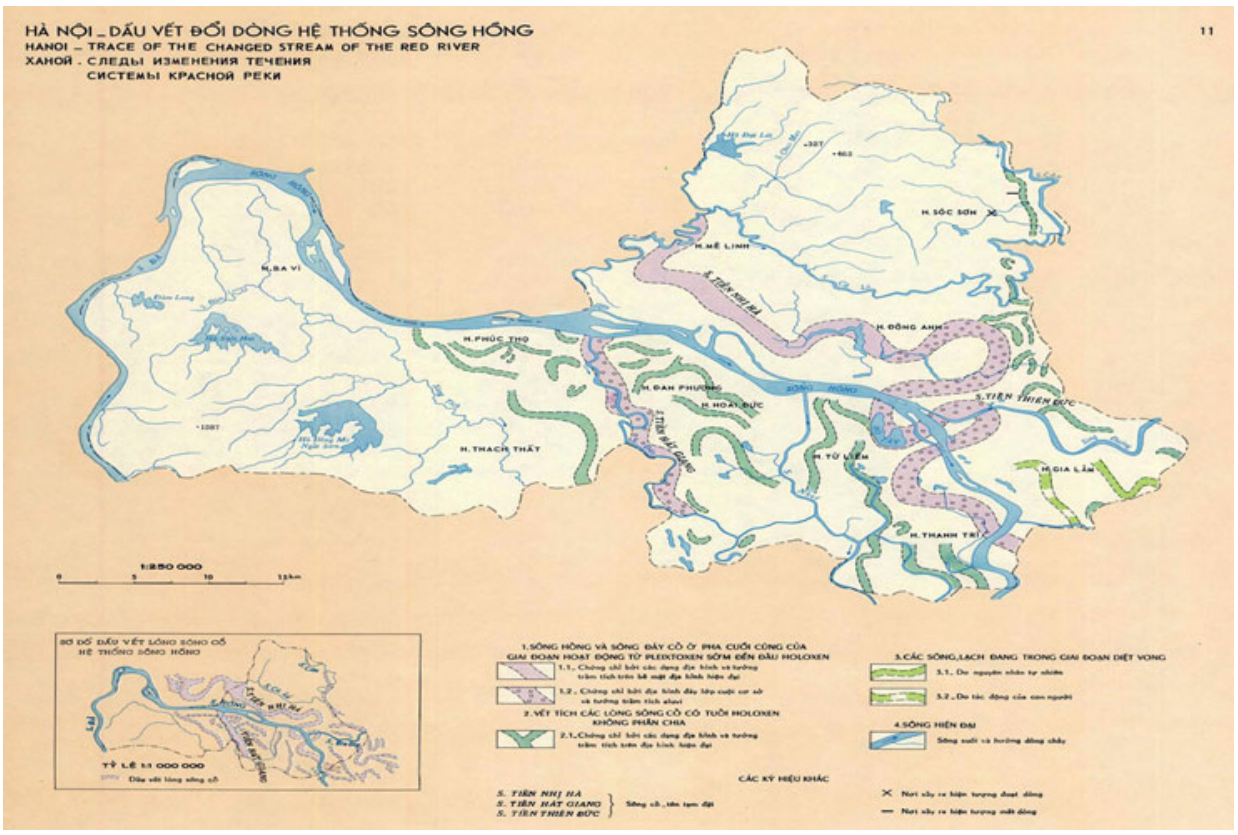

Figure 1. The Paleo-channel of the Red River. (Source: Nguyen Xuan Dao 1984: 11) 
component of the words Dền, Chiền, Triều, Viềng. These, according to the Vietnamese scholar Trần Quốc Vượng (1974: 90-92), were corrupt Viet pronunciations for the same Tai word Chiềng, meaning "the central area".

Another map which shows the historic evolution of the Red River delta (Maren 2004: Fig 2:2) illustrates the importance of the eastern delta (Figure 2). There are two significant points about this map: first, while the Red River delta has grown about ten times in the last 4000 years, between the first and second millennium AD much growth occurred in the eastern delta; and, second, astonishingly, the eastern Delta stopped growing completely around the tenth century AD.

What happened within these ten centuries at the eastern delta? Why had it accumulated so quickly and then stopped growing after the tenth or eleventh century? The political and economic powers centred at Luy Lau for about eight centuries would have made huge impacts on the rapid formation of the lower eastern Red River delta in the first millennium AD. Pollen core studies of the Red River delta indicate that during the period 1540 to 830 BP (AD 466-1176) the secondary taxon Lygodium is abundant (Zhen et al. 2006: 2425). This is considered an indicator of forest clearance, suggesting enlarged deforestation due to house construction and the expansion of agricultural fields. The increased sedimentation from the upper Red River delta would have accelerated the expansion of the eastern delta; and the eastern delta, virtually non-existent before the first century AD, emerged and then grew to double the size of the western delta in a matter of ten centuries. Such a speed of accretion needed strong discharge from the upper delta and there is only one river in the region that has such a huge capacity: the Red River. This seems to confirm the words of a leading Vietnamese historian Dao Duy Anh who pointed out that

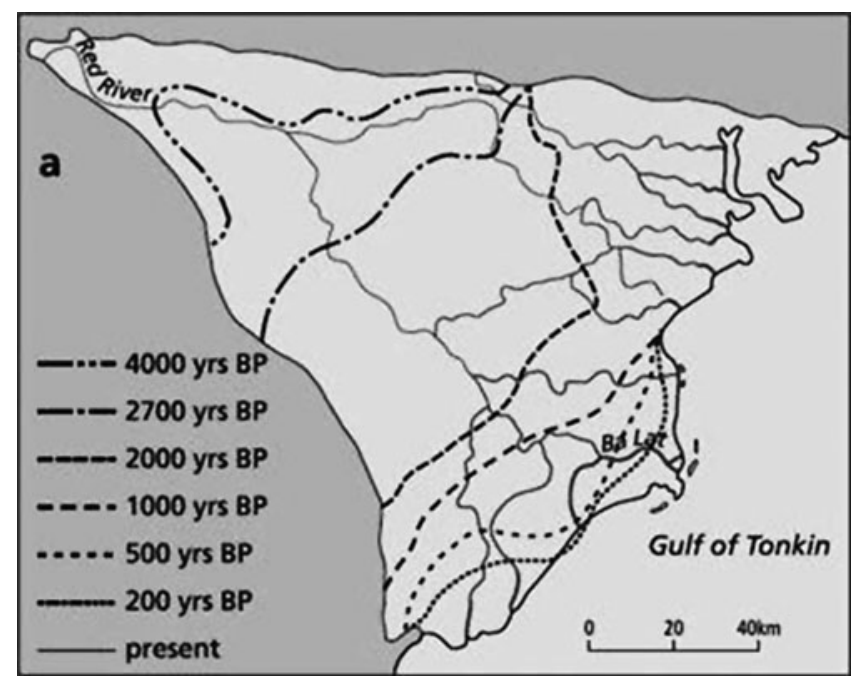

Figure 2. The historic evolution of the Red River delta. (Source: Maren 2004, Fig 2:2) 
before the fifteenth century AD the main stream of the Red River entered the sea through the Bach Dang river in the eastern delta (Dao 1964: 37). In other words, the contemporary main stream of the Red River which meets the sea between Nam Dinh and Thai Binh was a later development.

In the Han period, the former course of the Red River would have connected the major town centres of the Jiaozhi (Giao Chi in Vietnamese). Madrolle pointed out the importance of this area in his 1937 article, Le Tonkin Ancien, and stated that this region's colonial road no. 182 was, according to the local people, one of the most ancient paths in the country. Its construction dates back to a distant time, at least the beginning of the Chinese occupation. It is known as the 'Road of Invaders', and runs from the Dong Trieu district up to the heart of the delta (Madrolle 1937: 267). This is the very area where there are many Han tombs. According to Vietnamese historian Do Van Ninh, all the way along the sea from Yen Hung and Thuy Nguyen there are hundreds of Han tombs of the Eastern Han (25-220 AD) or later. The Han tombs are concentrated in the Uong Bi, Mao Khe, Dong Trieu, Chi Linh and Pha Lai areas; and all of them are major stations on the 'Road of Invaders'. Furthermore, in contemporary times, they are all major urban centres, testifying of the strategic importance of this route. In the single year of 1972, 33 Han tombs were excavated in Mao Khe, some of which were ten meters long and 31 meters high. As Do Van Ninh pointed out, "Mao Khe is now a remote mountainous area, but when the land of Thang Long was yet to be stabilised and Thai Binh, Hung Yen, and Nam Dinh were still under the sea, the fields of Mao Khe and Dong Trieu were the granaries of the region. It was settled by dense population and made it the target of explorations of the Han rulers" (Do Van Ninh 1989: 79).

Some points are important in establishing a fundamental understanding of this delta. First, the heart of today's lower delta was opened only after Vietnam's independence in the tenth century. Were a scholar to mark on a map each district under Tang rule, the map would reveal a strong concentration of the settlements in the upper, and eastern edge of the Red River delta and the Day River area. This corresponds well with the map of the Red River's old delta and the new delta (Figure 2). Second, during a considerable period under Chinese rule, the eastern edge of the delta was the political and economic centre of Vietnam. Third, and finally, the eastern delta served as one of the staging points for the opening and expansion of the western floodplain. This helps us to understand Madrolle's statement in the 1930s that this area was where the delta was born. (Madrolle 1937: 275)

In their article Climate change and human impact on the Song Hong (Red River) Delta, Zhen Li et al. (2006) show that up to 620 years ago the present main stream of the Red River, the Ba Lat Seagate, was still characterised by a high percentage of mangrove pollen. The mangrove pollen in this area disappeared between the fourteenth century and the present (Zhen Li et al. 2006: 15). This finding is supported by well documented historical records indicating 
that systematic and largely state-sponsored activities to open the western delta were taken place around this time period. More importantly, the data indicate a relatively late disappearance of the mangrove pollen at the current main distributary of the Red River, which suggests a later date of intensive cultivation. This raises the possibility that earlier concentrated human actions occurred elsewhere.

To date, most of the maps of the Red River delta describe a linear evolution of delta expansion. However, when the expansion is broken into different stages, as shown in Figure 2, it strongly hints to an untold story of reduction over the last ten centuries. Between the twelfth and fifteenth centuries, some significant changes occurred along the major course of the Red River. Put simply, when the main stream shifted its course from the eastern delta, water discharge to this area was greatly reduced. The reduced sedimentation, in turn, reduced the speed of the natural expansion of the eastern delta and brought it to a standstill. Reduced freshwater gave way to the salty water intrusion to the eastern delta. And, finally, the damaged soil which lacked oxygen made the land even more vulnerable to typhoon damage. The end result was the serious and continuing erosion of the coast along the eastern delta.

Erosion and sedimentation are the differing results of the same environmental event. In a coastal area, soil eroded from one coast is frequently carried to the coast nearby. Thus, in the last 150 years, the Qinzhou Bay in Guangxi, which shares the Gulf of Tongking with the Red River delta, has experienced a westward expansion and eastward reduction due to human activities such as reclamation and embankment that "accelerated the evolution from the low tidal flat to the high tidal flat" (Li Zhen et al. 2010: 1). The same phenomenon is observed in the Pearl River delta, where geologists point out an overall trend of that river system over the last two thousand years. In this case the waterways of the right hand side (eastern) shrank while those on the left hand side (western) grew, and the main stream shifted to the west.

While we cannot see this historical evolution with our own eyes, what is happening in the current Red River delta will shed light on the history of the last few hundred years. In the Red River delta, a recent report by Vietnamese scholars point out that "in the coastal sections far from river mouths occur erosion, while in river mouth areas occurs sedimentation with high rate as in Ba Lat and Day river mouths" (Ngo Ngoc Cat et al. 2006: 11). This seems to indicate that the trend of the Red River delta is similar to the Guangxi and Guangdong coast: the growth of the western delta is paired to a related reduction in the eastern delta. In the next section, the story of land siltation and the expansion of the western Red River delta will be told in parallel to the history of Hanoi. 


\section{Thang Long: Ascended from the Water}

The Hanoi area would once have been where the Red River met the sea (Nishimura 2005). Recent excavations in the Thang Long citadel found 13 types of snail fossils which typically live in lakes or ponds (Dinh Van Thuan and Nguyen Dich Dy 2012: 210). As we can see in Figure 1 (above), today's largest lake in Hanoi, the West Lake (Ho Tay), was part of a paleo-channel of the Red River. This means that a large area of modern Hanoi, including the area of the royal palace, was at the lower altitude of the Red River delta, which is why geologists call it the Hanoi Valley.

Hanoi is known as the 'Navel of the Dragon' (Long Do). This name indicates both its location in the delta and its altitude. Hanoi's altitude is considerably lower than that of Co Loa and Luy Lau, the two older capitals. Between the third century BC and the eighth century AD, Hanoi was probably still covered by lakes and ponds, and enveloped by thick forests. In the words of the Han general Ma Yuan (Ma Vien), the Lang Bac area where he was to defeat the Trung Sisters was a "flood on the earth and fog in the sky, poisonous air steamed people in various ways. [The miasma] was so strong that one could see birds fall into water one after the other [because they could not go through the thick air]." ${ }^{2}$ The wooded areas that were once around modern Hanoi are recalled in place names: Gia Lam (Good Forest), Truong Lam (Long Forest), Mai Lam, and Dong Ngan (Mountain Forest) (Do Van Ninh 1989: 58) More concrete evidence is found from a Hanoi area pollen study which indicates that in the Holocene, Camptotheca Acuminata, known in Vietnamese as 'Happy Tree' but now never seen in the contemporary Vietnam, was once abundant in the Red River catchment area, particularly the Hanoi and Ha Tay areas (Nguyen Thuy Duong 2006: 8).

Hanoi became the capital Daluo (Dai La) of the Tang administration in AD 767 because these lakes or ponds were filled up in the previous eight centuries. In other words, the imperial citadel of Thang Long (Ascending Dragon) built in the eleventh century had indeed emerged from the water. The ponds, lakes, and back waters of the Red River, upon which Thang Long was constructed, were filled in by the deforestation and erosion of the higher grounds nearby, a result of the combined efforts of humans and nature, a process that we are yet to chart out. It would not be surprising if the silted land was built up because of farming and land clearing in the Son Tay-Phu Tho area at the upper Red River delta, the oldest area occupied by Viet and Tai speakers; and the Bac Ninh area, where the Han administration office was based for 600 years between the early first and seventh century AD.

2 后汉书。马援传： “当吾在浪泊、西里间, 虏未灭之时, 下潦上雾, 毒气重蒸, 仰视飞感跕 跕坚水中”. 
As late as the nineteenth century, Hanoi was still covered by many ponds and lakes and surrounded by three rivers. All twelve gates of the citadel were near to rivers (Figure 3). These water gates were where the markets (cho ô) were situated.

The story of one of Hanoi's hills is indicative of the city's shifting terrain. Long Do Hill (Long Do Son or 'Navel of the Dragon'; also known as Nung Son) was the highest point in eleventh century Thang Long and it was on this spot the main palace (Can Nguyen Palace) was built. This hill is no longer visible in today's Hanoi. Over time, as the rest of the city silted up, the Long Do Hill became gradually less prominent, until now it is only on a relatively higher patch of ground within the Thang Long citadel.

The emergence of Thang Long-Hanoi in the first millennium is a significant phase in land siltation and the expansion of the western mid-Red River delta. This process accelerated after Dai Viet's independence in the tenth century. The independent Dai Viet was born into a fortunate period of favourable climate which lasted for about three hundred years. Data reconstructed from the tree-ring widths of cypress trees in central Vietnam indicates that between the tenth and the latter half of the thirteenth centuries, Southeast Asia enjoyed an unusually warm period with persistent La Niña-like conditions, which tended to produce not only an increase in monsoonal rains, but a greater annual

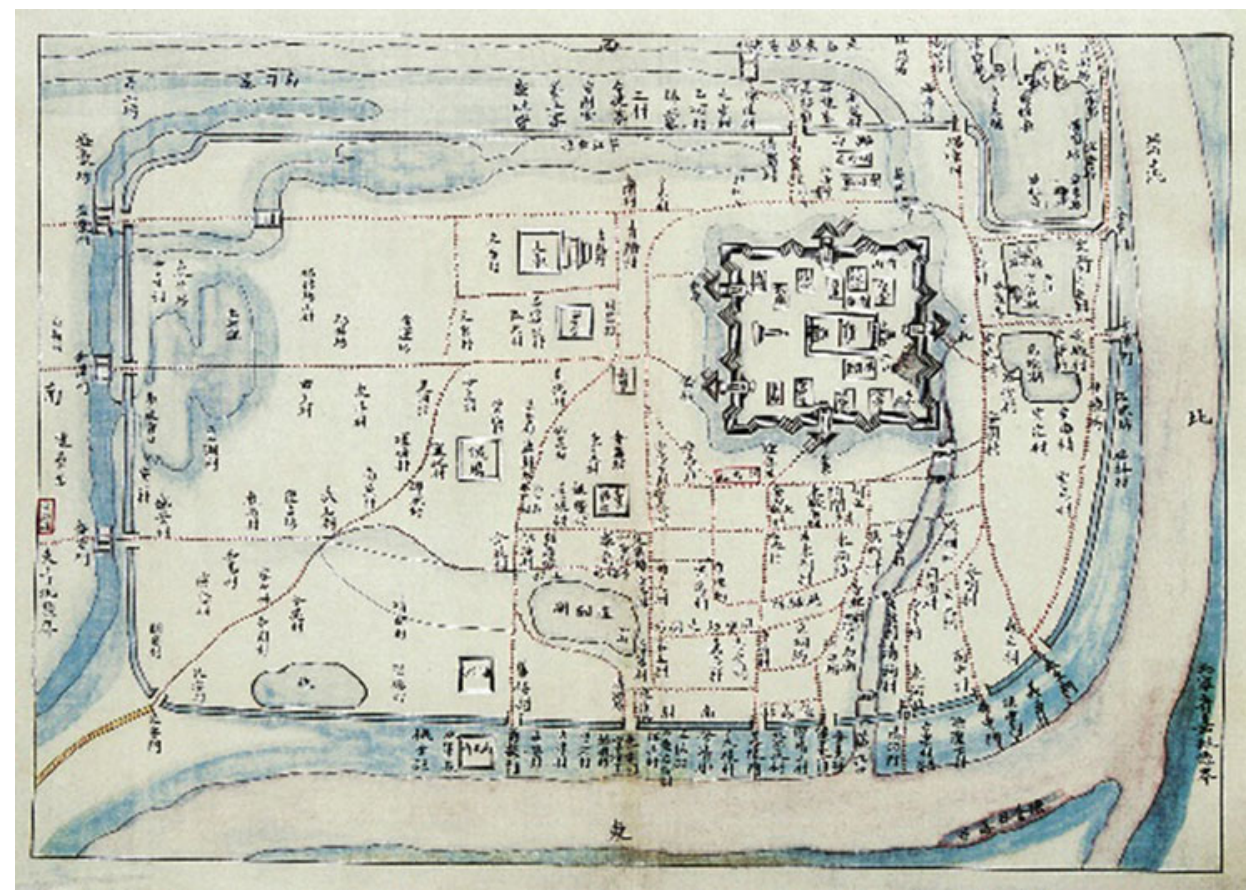

Figure 3. Nineteenth century Hanoi. (Source: Ngo Duc Tho et al. 2003: 8) (Image courtesy of the Han-Nom Institute, Hanoi) 
distribution of rainfall, with longer monsoons and shorter dry seasons (Lieberman and Buckley 2012: 16).

The upper Red River area must have experienced continued growth in the Ly and Tran periods thanks to the more reliable rain-fed harvests of the tenth to the thirteenth centuries. Many large temples and pagodas were built in the Son Tay area, and hundreds of palaces were built in the capital. All these suggest economic expansion, accumulated wealth and population growth. But logging and slash-and-burn agriculture in the hills aggravated erosion of the upper delta area and increased the frequency and severity of floods in the middle delta. The imperial palaces were direct victims of these floods in 1236, 1238, and 1243 (Lieberman and Buckley 2012: 19). These frequent floods might have spurred the construction of the Dinh Nhi dike in 1248. It looks as if the immediate drive for the Dinh Nhi dike could have been to protect the capital area, where the king, queen, court ladies, and officers were located. The increased floods and the building of the Dinh Nhi dike indicate the impact of active human activities and erosion on the upper Red River area.

\section{Conclusion}

Like many rivers in the world, the Red River has gone through many dramatic changes, but to date we know very little about the how, the why, and the when of those changes. The only static components of the Red River valley and delta are its mountains and geological deposits, everything else has changed over time. As outlined in this historical sketch, aspects of these changes included the climate and landscape; shifting river courses, erosion and deposition; shafting patterns of vegetation; and soil development and degradation. These forces combined have shaped the development of historical trade routes, as well as the rise and fall of major towns. This article is but a humble and tentative attempt to sketch some of these changes.

\section{References}

Buckley, B. M., Fletcher, Roland, Wang, Shi-Yuan Simon, Zottoli, Brian and Pottier, Christophe. 2014. Monsoon extremes and society over the past millennium on mainland Southeast Asia. Quaternary Science Reviews 95, 1-19.

Dao, Duy Anh. 1964. Dat nuoc Viet Nam qua cac doi [Vietnamese territories throughout history], Hanoi: Khoc Hoc.

Dinh, Van Thuan and Nguyen, Dich Dy. 2012. Dac diem moi truong dia chat - co dia ly Holocene giua - muon khu Hoang thanh Thang Long-Hanoi [Characteristics of geological environment and paleo geography of the mid-late Holocene period of the Thang Long-Hanoi area]. In Nguyen Quang Ngoc and Momoki Shiro (eds.), Selected Japanese-Vietnamese papers on the Thanh Long Citadel, pp. 205-218. Tokyo: National Research Institute for Cultural Properties. 
Do, Van Ninh. 1989. Co Loa. In Do thi co Viet Nam [Ancient cities of Vietnam], pp.58-76. Hanoi: Vien Su Hoc.

Do, Van Ninh. 1989. Luy Lau. In Do thi co Viet Nam [Ancient towns of Vietnam], pp.77-91. Hanoi: Vien Su Hoc.

Elvin, Mark and Su, Ninghu. 1998. Action at a distance: the influence of the Yellow River on Hangzhou Bay since AD 1000. In Mark Elvin and Liu Ts'ui-jung (eds.), Sediment of Time: Environment and Society in Chinese History, pp. 344-407. Cambridge: Cambridge University Press.

Hoekstra, P. and van Weering, Tj.C.E. 2007. Morphodynamics of the Red River Delta, Vietnam. Journal of Asian Earth Sciences, 29(4), 508-584.

Le, Ba Thao. 1977. Thien nhien Viet Nam [Nature of Vietnam]. Hanoi: Nha xuat ban Khoa hoc ky thuat.

Lee, James. 2012. 中国西南边疆的社会经济 [Society of economy of China's southwestern border region]. Tran. Lin Wenxun and Qin Shucai. Beijing: Renmin chubanshe.

Li, Zhen, Li, Zhen, Weiguo, Zhang, Li, Jie, Meng, Xianweij, Lui, Lejun, and Li, Chaoxin. 2010. Pollen assemblage and sedimentary environment evolution in the coastal zone in Qinzhou Bay, Guangxi Province. Quaternary Science, 30(5), 1-11.

Lieberman, Victor and Buckley, Brendan. 2012. The Impact of Climate on Southeast Asia, circa 950-1820: New Findings, Modern Asian Studies, 46(5), 1049-1096.

Madrolle, Claudias. 1937. Le Tonkin ancien. Bulletin de l'École française d'ExtrêmeOrient 37(2), 263-333.

Ngo, Duc Tho, Nguyen, Van, and Papin, Philippe (eds.). 2003. Dong Khanh dia du chi [The Descriptive Geography of the Emperor Dong Khanh]. Hanoi: Ecole Practique des Hautes Etudes/Vien Nghien cuu Han-Nom/Ecole francaise d'Extreme-Orient.

Ngo, Ngoc Cat, Pham, Huy Tien, Do, Dinh Sam, Nguyen, and Ngoc Binh. 2006. Status of Coastal Erosion of Vietnam and Proposed Measures for Protection. New York: Food and Agriculture Organization of the United Nations. Available at: http:// www.fao.org/forestry/11286-08d0cd86bc02ef85da8f5b6249401b52f.pdf (accessed on 16 November 2015).

Nguyen, Thuy Duong. 2006. Palaeoecology of the Red River Delta in the Holocene: A palynological Approach. Unpublished doctoral dissertation, Greifswald University.

Nguyen, Xuan Dao. 1984. Atlas Hanoi. Hanoi: Ban chi dao dieu tra co ban tong hop Thanh pho Ha Noi.

Nishimura, Masanari. 2005. Settlement patterns on the Red River plain from the late prehistoric period to the 10th century AD, Indo-Pacific Prehistory Association Bulletin 25, 99-108.

Ren, Mei-e, 任美锷. 2006. 黄河的输沙量:过去、现在和将来一一距今 15 万年以来的 黄河泥沙收支表 [Sediment Discharge of the Yellow River, China: Past, Present and Future-A Synthesis], 地球科学进展 [Advances in Earth Science] (6), $551-563$.

Shiba, Yoshinobu. 2000. 宋代江南经济史研究 [An economic history of the Yangzi River Delta in the Song dynasty], trans. Fang Jian, Nanjing: Jiangsu renmin chubanshe.

Tran, Quoc Vuong. 1974. Doi bo Ngu Huyen Khe (Ha Bac) [On the banks of the Ngu Huyen Khe]. Khao co hoc [Journal of Archaeology] (16), 90-92.

Tran, Tri Doi. 2008. Ten goi cua Song Hong: dau tich bieu hien net da dang van hoa trong lich su nguoi Viet [The names of the Red River: traces indicating diversities of culture in Vietnamese history]. Paper present at the third conference of Vietnamese Studies, Hanoi, 4-7 December. 
Zhen, Li, Yoshiki, Saito, Matsumoto, Eiji, Wang, Yongil, Tanabe, Susumu, Vu, Quang Vu. 2006. Climate change and human impact on the Song Hong (Red River) Delta, Vietnam, during the Holocene. Quaternary International 144(1), 24-25.

Zhou, Qiong. 周琼. 18 19 世纪云南玉米和马铃薯的生态史研究 [A study on corn and potato cultivations in eighteenth and nineteenth century Yunnan]. Available at: http://www.xnhjs.com/chengguo/2011/0321/157.html (accessed on 22 April 2014). 